DOI: $10.21802 /$ artm.2020.1.13.180.

УДК 616-037+612.17

\title{
ЗАСТОСУВАННЯ ПРОГНОСТИЧНИХ ШКАЛ У СУЧАСНІЙ КАРДІОЛОГІЧНІЙ ПРАКТИЦІ (ЧАСТИНА 1)
}

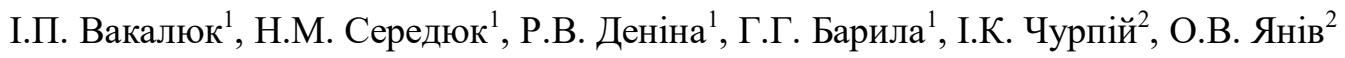 \\ Івано-Франківський національний медичний університет, \\ ${ }^{l}$ кафедра внутрішньої медицини № 2 та медсестринства, \\ ${ }^{2}$ кафедра фізичної реабілітації, ерготерапії з курсом фізичного виховання, \\ м. Івано-Франківськ, Украӥна, \\ ORCID ID: 0000-0002-4430-6816, ORCID ID: 0000-0002-3616-2445,ORCID ID: 0000-0001-8196-7130, \\ ORCID ID: 0000-0002-0940-1092, ORCID ID: 0000-0003-1735-9418, ORCID ID: 0000-0003-0921-3304, \\ e-mail: roksolanadoc@ukr.net
}

Резюме. У даній статті представлені сучасні найбільш популярні та добре зарекомендовані шкали та калькулятори, які використовуються у практичній медицині. Великий об'єм інформації може створювати перепони в узагальнені даних для отримання достовірної оцінки стану пацієнта та прийняття рішення щодо діагностики, подальшої тактики лікування, оцінки його ефективності та подальшого прогнозу. Позитивним моментом у застосуванні шкал $є$ й простота використання, що дозволяє користуватися ними в поліклініках, сімейних амбулаторіях та стаціонарах.

Представлені шкали дозволяють проводити систематичну оцінку коронарного ризику, прогнозувати довготривалі ризики розвитку кардіоваскулярних подій, смертельних результатів та оцінка тривалості антитромбоцитарної терапії у пацієнтів при гострому коронарному синдромі, визначати ризик тромбоемболічних ускладнень у пацієнтів з фібриляцією передсердь, оцінити хірургічний ризик, пов'язаний із реваскуляризацією міокарда та аорто-коронарним шунтуванням. Також фактори ризику, що використовуються в шкалах, часто бувають неспецифічними і можуть впливати на прогноз інших захворювань. Наприклад, вік, куріння, артеріальний тиск, патологія нирок, клас серцевої недостатності, анемія, рівні ліпідів враховуються в багатьох шкалах. Тому шкали, розроблені для одного захворювання, можуть виявитися корисними і для інших патологій.

Отже, використання прогностичних шкал у практиці допомагає лікарям оцінити можливі ризики розвитку несприятливих подій для груп пацієнтів з подібними умовами, і на цій основі приймати більш ефективні діагностичні і лікувальні рішення з обов'язковим урахуванням позиції кожного пацієнта.

Ключові слова: прогностичні шкали, серцево-судинний ризик.

Вступ. Швидка і точна діагностика серцевосудинних захворювань (ССЗ), вибір лікувальної програми 3 оптимальним співвідношенням «користь/ризик» залишаються пріоритетними завданнями практикуючого кардіолога. Звичайний емпіричний підхід може обмежувати спеціаліста, не завжди давати стабільний результат, не бути прозорим і обмеженим в удосконаленні діагностичних можливостей. Одним із шляхів підвищення ефективності розв'язуваних лікарем завдань $\epsilon$ використання спеціальних шкал для оцінки ймовірності захворювань у даний момент (діагностика) або в майбутньому (прогноз) [5, 20].

\section{Переваги прогностичних шкал:}

- уніфікація прийняття рішення;

- немає суттєвої залежності від досвіду та кваліфікації лікаря;

- кількісна оцінка стану і прогнозу;

- автоматичний розрахунок при наявності електронної історії хвороби;

- можливість контролю.

Недоліки прогностичних шкал:

- груповий прогноз;

• облік невеликого числа предикторів;
- невизначеність часового періоду прогнозу;

- статичний характер прогнозу;

- залежність від популяції;

- обмеженість певним захворюванням або варіантом хвороби;

- численність шкал і складність вибору;

- відсутність стандартів.

У таблиці 1 представлена узагальнена класифікація шкал.

У даній статті (частина 1) наводимо огляд основних шкал, які рекомендовано використовувати у кардіологічній практиці.

Шкали в кардіології умовно можна розділити наступним чином:

$\checkmark$ Визначення загального серцево-судинного ризику:

- шкала SCORE (Systematic Coronary Risk Evaluation)

- систематична оцінка коронарного ризику;

- фрамінгемська шкала (Framingham risk score - FRS ) розрахунку 10 -літнього ризику розвитку кардіоваскулярних подій в осіб, які не мають клінічних проявів кардіоваскулярної патології; 
- PROCAM - метод розрахунку глобального десятирічного ризику розвитку ішемічної хвороби серця (IXC) у жінок і чоловіків;

- шкала ASSIGN - оцінка 10-річного ризику розвитку кардіоваскулярної патології, включаючи летальність від кардіоваскулярних захворювань, IXC, цереброваскулярної хвороби під час виписки зі стаціонару або втручання на коронарній артерії;
- шкала ризику Рейнольдса оцінює 10-річний сумарний ризик кардіоваскулярних подій (IM, ішемічного інсульту, реваскуляризації коронарних артерій і летальності від кардіоваскулярних захворювань).

Класифікація прогностичних шкал

\begin{tabular}{|c|c|}
\hline Критерії & Види \\
\hline Галузь застосування & $\begin{array}{l}\text { - Універсальні } \\
\text { • Спеціалізовані } \\
\end{array}$ \\
\hline Період прогнозу & $\begin{array}{l}\text { - Короткотривалі (до } 1 \text { міс.) } \\
\text { - Середньої тривалості (1 міс. - } 1 \text { рік) } \\
\text { • }\end{array}$ \\
\hline Розпізнавання груп ризику (С-статистика) & $\begin{array}{l}- \text { Відмінне }(0,91-1,00) \\
\text { - Дуже гарне }(0,81-0,90) \\
\text { - Гарне }(0,71-0,80) \\
\text { - Середнє }(0,61-0,70) \\
\text { - Погане }(<0,61)\end{array}$ \\
\hline Придатність для практики & $\begin{array}{l}\text { - Валідизовані } \\
\text { • Невалідизовані } \\
\end{array}$ \\
\hline Етап лікування & $\begin{array}{l}\text { • Діагностичні } \\
\text { • Лікувальні }\end{array}$ \\
\hline
\end{tabular}

\section{$\checkmark$ Ішемічна хвороба серця (IXC):}

- претестова імовірність IXC у пацієнтів з больовим синдромом у грудній клітці;

- тест-імовірність IXC за клінічними ознаками;

- HEART Score - титрування пацієнтів із загруднинним болем (можливим ГКС), які знаходяться у кареті швидкої допомоги, приймальному покої чи відділені невідкладної допомоги;

- COMPASS - альтернативна схема для скринінгу пацієнтів із підтвердженою IXC (STEMI, NSTEMI, стабільна стенокардія) для визначення доцільності комбінованої антитромботичної терапії.

$\checkmark$ Гострий коронарний синдром (ГКС):

- GRACE - оцінка ризику внутрішньолікарняної летальності, смертності і розвитку IM протягом півроку;

- TIMI, TIMI II - оцінка ризику смерті, IM, рецидиву стенокардії або необхідності невідкладної реваскуляризації у хворих з ГКС без елевації сегмента ST та з елевацією сегмента ST;

- GUSTO - оцінка 30-денного прогнозу при ГКС;

- PURSUID - оцінка ризику смерті / IM у пацієнтів з ГКС без елевації сегменту ST;

- CRUSADE - оцінка ризику кровотеч у період госпіталізації у хворих на ГКС без елевації сегменту ST (NSTEMI);

- CADILAC - оцінка короткострокового і довгострокового прогнозування смертельного результату у хворих з IM без елевації сегменту ST, які перенесли ЧКВ;

- STIMUL - оцінка ризику госпітальної летальності у пацієнтів на ГКС з елевацією сегмента ST;
- DAPT та PRECISE-DAPT - оцінка тривалості подвійної антитромбоцитарної терапії у пацієнтів 3 ГКС;

- SYNTAX Score - шкала оцінки важкості ураження коронарного русла при застосуванні різних тактик реваскуляризації міокарда у пацієнтів із багатосудинним ураженням коронарних артерій;

- шкала ризику розвитку контраст-індукованої нефропатії після коронарних втручань (по Mehran);

- STS Score - шкала оцінки хірургічного ризику, повязаного із аорто коронарним шунтуванням (АКШ);

- CHOІСЕ - вибір первинної стратегї реканалізації при хронічній оклюзії коронарних артерій);

- J-CTO - шкала для прогнозування наслідків ендоваскулярних втручань при хронічній оклюзії коронарних артерій;

- PROGRESS CTO complication score - шкала розрахунку ризику виникнення ускладнень при ЧКВ;

- CL - шкала прогнозування успіху процедури (технічний успіх процедури при відсутності значимих ускладнень на госпітальному етапі.

\section{$\checkmark$ Порушення ритму (фібриляція передсердь):}

- CHA2DS2VASc (шкала для оцінки ризику тромбоемболічних ускладнень у пацієнтів з фібриляцією передсердь);

- HAS-BLED (оцінка ризику кровотечі у пацієнтів із фібриляцією передсердь);

- TIMI-AF (оцінка сумарного ризику ускладнень у пацієнтів з фібриляцією передсердь для вибору опти- 
мальної антикоагулянтної терапії (варфарин або НОAK) [10];

- SAMe-TT $\mathrm{R}_{2}$ (шкала розрахунку тактики вибору між новими пероральними антикоагулянтами (NOAC) та антагоністом вітаміну К) [2];

- CAАР-AF (оцінка ефективності катетерної абляції у пацієнтів 3 фібриляцією передсердь) [34];

- HEMORR2HAGES Score (шкала оцінки ризику крововиливів у пацієнтів похилого віку з фібриляцією передсердь) [14].

\section{$\checkmark$ Серцева недостатність:}

- Мінесотський опитувальник якості життя;

- ШОКС (шкала оцінки клінічного стану важкості пацієнта при ХCH);

- EFFECT (шкала оцінки 30 денної і річної смертності у пацієнтів з ХCH).

$\checkmark$ Тромбоемболія легеневої артерії (ТЕЛА):

- Geneva Score (Revised) for Pulmonary Embolism (шкала ризику легеневих тромбоемболій);

- Канадська шкала ризику розвитку ТЕЛА;

- PESI (додаткова шкала стратифікації ризику при ТЕЛА у пацієнтів невисокого ризику);

- шкала Уеллса (оцінка клінічної ймовірності ТЕЛА).

$\checkmark$ Оцінка ризику кардіохірургічних втручань:

- шкала Goldman - оцінки ризику кардіальних ускладнень при позасердцевих операціях.

- EuroSCORE (шкала оцінки ризику при кардіохірургічних втручаннях);

- EuroSCORE II EuroSCORE (шкала оцінки ризику при кардіохірургічних втручаннях- оновлена версія);

- AMBLER Score (шкала ризиків при оперативних втручаннях на клапанах серця (з і без КШ).

$\checkmark$ Методи прогнозування ризиків при кардіоваскулярних захворюваннях в умовах коморбідності [26, 27]:

- індекс Чарлсона (Charlson Index) - використовують для прогнозу летальності;

- Кумулятивна шкала рейтингу захворювань (Cumulative Illness Rating Scale - Cirs) оцінює всі системи організму без специфічних діагнозів;

- індекс поєднаної хвороби (Index of Coexisting Disease - ICED) враховує тяжкість захворювання i непрацездатність.

Найбільш поширеною і простою у використанні є шкала SCORE (Systematic COronary Risk Evaluation). SCORE - це абревіатура англійських слів «систематична оцінка коронарного ризику». Дана шкала була запропонована групою експертів Європейського товариства кардіологів у 2003 р. і розроблена на підставі результатів досліджень, проведених в 12 європейських країнах та модифікована у 2019 році. Шкала - це система квадратів, в якій застосовано принцип світлофора - три основні кольори: зелений - це низький ризик, що відповідає $1 \%$ або менше, жовтий колір - увага - помірний ризик і коливається в межах 2-4 \%, червоний колір - небезпека 5\% і більше. Для чіткішої диференціації застосовано відповідні відтінки цих кольорів $[9,20]$.

C два варіанти шкали SCORE: для країн 3 низьким ризиком і країн з високим ризиком серцевосудинних захворювань (до них відноситься Україна) (рис. 1, рис. 2). Для оцінки сумарного ризику смертельного серцево-судинного захворювання за допомогою калькулятора необхідно вказати у відповідних полях стать, вік, рівень систолічного артеріального тиску, чи палить пацієнт і рівень загального холестерину. Отримана цифра - ймовірність настання смертельного результату від серцево-судинного захворювання упродовж найближчих 10 років, виражену у відсотках. відсотках.

Критерії оцінки ризиків наступні.

Дуже високий ризик:

- Доведений атеросклероз будь-якої локалізації (за даними ангіографії, МРТ, стресехокардіографії, дуплексного сканування аорти та іï гілок, сонних й інших центральних артерій, а також перенесений IM, ГКС, реваскуляризація міокарда (ЧКВ, АКШ) та інші процедури пов'язані 3 артеріальною реваскуляризацією, ішемічний інсульт, проліферуючий атеросклероз периферичних артерій).

- Цукровий діабет (тип 1 або тип 2) з одним і більше факторі ризику i/або пошкодження органівмішеней (наприклад, мікроальбумінурія 30-300 мг/добу).

- Хронічна хвороба нирок з нирковою недостатністю (ШКФ <30 мл/хв / 1,73 м2).

- Сумарний серцево-судинний ризик за шкалою SCORE $\geq 10 \%$ у осіб без клінічних проявів СC3.

Високий ризик:

- Значно підвищений рівень окремих ФР, наприклад, сімейна дисліпідемія і АГ високого ступеня тяжкості.

- Цукровий діабет (тип 1 або тип 2), без ФР і ураження органів-мішеней

- Хронічна хвороба нирок помірного ступеня тяжкості (СКФ 30-59 мл/хв/1,73 м2).

- Сумарний CC ризик за шкалою SCORE $\geq 5$ \% i $<10 \%$ у осіб без клінічних проявів СС3.

Помірний ризик: сумарний СС ризик за шкалою SCORE $\geq 1$ i $<5 \%$.

Низький ризик: сумарний СС ризик за шкалою SCORE $<1 \%$.

Також, розроблені відповідні шкали для пацієнтів 3 різними рівнями холестерину (ЛПВЩ 0,8 ммоль/л, 1,0 ммоль/л, 1,4 ммоль/л, 1,8 ммоль/л ) та для осіб молодше 40 років (рис. 3 ). 
Шкала SCORE десятирічного кардіоваскулярного ризику фатального серцево-судинного захворювання

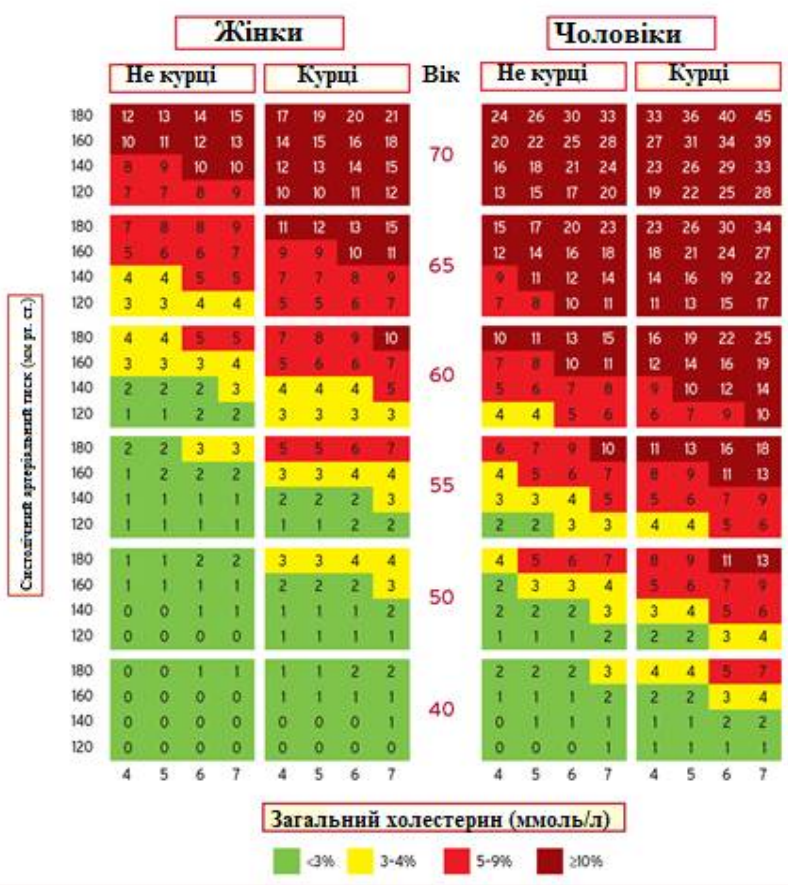

Рис. 1. SCORE для населення Свропи з високим ризиком серцево-судинних захворювань

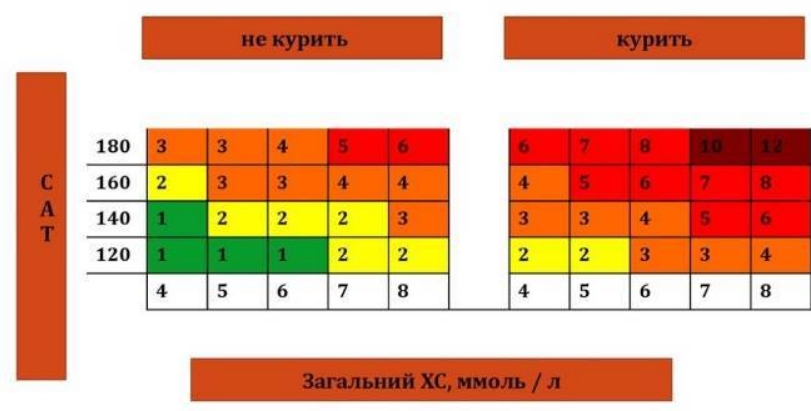

Рис. 3. Таблиця відносного ризику розвитку ССЗ для осіб молодше 40 років

Найбільш поширеним захворюванням у кардіології $\epsilon$ IXC. Діагностика та обстеження пацієнта зі стабільною IXC включає клінічний огляд, лабораторне дослідження (визначення показників ліпідного обміну, глюкози крові, інших біохімічних даних), спеціальні кардіологічні дослідження (проби 3 дозованим фізичним навантаженням, проби 3 візуалізацією коронарних артерій тощо). Такий комплекс досліджень при підозрі на IXC необхідний для встановлення діагнозу, а також для визначення супутньої патології, факторів, які погіршують перебіг основного захворювання, стратифікації ризику та оцінки ефективності терапії. Хоча існує багато методів неінвазивних досліджень, які використовуються для підтвердження діагнозу стабільної IXC, опти-
Шкала SCORE десятирічного кардіоваскулярного ризику фатального серцево-судинного захворювання

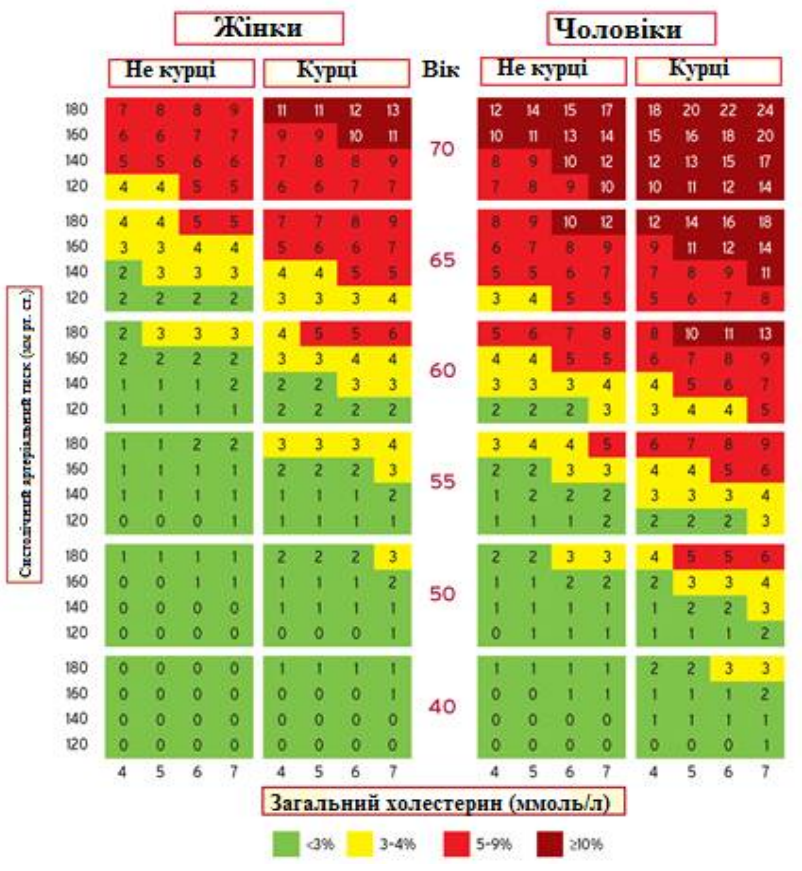

Рис. 2. SCORE для населення Свропи 3 низьким ризиком серцево-судинних захворювань

мальне застосування наявних ресурсів потребує попереднього визначення показника пре-тестової імовірності захворювання, що базується на простих клінічних даних [9, 13, 32, 35].

Оскільки існує взаємозалежність між претестовою імовірністю (клінічна вірогідність, що даний пацієнт має IXC) i результатами доступних діагностичних методів (вірогідність, що пацієнт має захворювання, якщо тест позитивний, чи немає його, якщо тест негативний), при проведенні діагностичного тестування необхідно брати до уваги показник претестової імовірності $[13,32]$.

За чинними міжнародними документами визначення показника пре-тестової імовірності (табл. 2) базується на останніх дослідженнях щодо поширеності IXC. Цей же показник пропонується як стартовий «крок» у діагностичному алгоритмі захворювання.

Білі клітинки у таблиці відповідають низькій пре-тестовій імовірності IXC $<15 \%$, хворі 3 такими показниками не потребують подальшого тестування на IXC.

Блакитні клітинки - відповідають середній низькій пре-тестовій імовірності IXC 15-65 \%, у таких випадках для первинної діагностики може бути використаний тест $з$ дозованим фізичним навантаженням. Проте більшу діагностичну інформативність для виявлення ішемії мають неінвазивні тести 3 візуалізацією міокарду. У молодих пацієнтів можуть розглядатись радіологічні методи діагностики. 
Рожеві клітинки - відповідають середній високій пре-тестовій імовірності IXC 66-85\%, для підтвердження діагнозу IXC рекомендовані неінвазивні функціональні тести з візуалізацією.
Темно-червоні клітинки - висока претестова імовірність IXC > $85 \%$, передбачається, що у таких пацієнтів наявна стабільна IXC. Вони потребують виключно стратифікації ризику.

Пре-тестова імовірність IXC* у паціснтів з больовим синдромом у грудній клітці

\begin{tabular}{|c|c|c|c|c|c|c|}
\hline \multirow{2}{*}{ Вік } & \multicolumn{2}{|c|}{ Типова стенокардія } & \multicolumn{2}{|c|}{ Атипова стенокардія } & \multicolumn{2}{|c|}{ Не-ангінальний біль } \\
\cline { 2 - 7 } & Чоловіки & Жінки & Чоловіки & Жінки & Чоловіки & Жінки \\
\hline $30-39$ & 59 & 28 & 29 & 10 & 18 & 5 \\
\hline $40-49$ & 69 & 37 & 38 & 14 & 25 & 8 \\
\hline $50-59$ & 77 & 47 & 49 & 20 & 34 & 12 \\
\hline $60-69$ & 84 & 58 & 59 & 28 & 44 & 17 \\
\hline $70-79$ & 89 & 68 & 69 & 37 & 54 & 24 \\
\hline 80 & 93 & 76 & 78 & 47 & 65 & 32 \\
\hline
\end{tabular}

Примітка:*Імовірність обструктивної IXC обчислювалась для пацієнтів 35, 45, 55, 65,75 і 85 років

Тест оцінки імовірності IXC за клінічними ознаками (табл. 3) необхідно використовувати з урахуванням іншої клінічної інформації, зокрема характеру болю, наявності факторів ризику (ФР) та супутньої патології, яка збільшує вірогідність IXC.
Сума балів 2 та менше дозволяє виключити діагноз IXC з вірогідністю 81 \%, від 3 до 5 - підтвердити діагноз з вірогідністю $87 \%$.

Тест оцінки імовірності IXC за клінічними ознаками

\begin{tabular}{|l|l|l|}
\hline \multicolumn{1}{|c|}{ Показник } & \multicolumn{1}{|c|}{ Значення } & Бал \\
\hline \multirow{2}{*}{ Стать/вік } & Чоловіки > 55 років & 1 \\
\cline { 2 - 3 } & Жінки > 65 років & 1 \\
\hline Встановлений діагноз судинної патології & Так & 1 \\
\hline Хворий визначає біль як «біль у серці» & Так & 1 \\
\hline Біль посилюється при фізичному навантаження & Так & 1 \\
\hline Біль не провокується пальпацією грудної клітки & Так & 1 \\
\hline
\end{tabular}

Існує безліч міжнародно визнаних $\mathrm{i}$ апробованих реєстрів і шкал ризику ГКС. Відповідно до рекомендацій Американської асоціації кардіологів (American Heart Association (ACC/AHA)) і Європейського товариства кардіологів (European Society of Cardiology (ESC)) найбільш часто використовуваними в практичній кардіології є такі реєстри і шкали: PURSUIT, TIMI, GRACE, CRUSADE (для хворих з ГКС без елевації сегмента ST), TIMI II (для хворих з ГКС і елевацією сегмента ST); CADILLAC, SYNTAX, DAPT, PRECISE-DAPT, GUSTO, PAMI (при направленні хворих на черезшкірні коронарні втручання) та інші.

HEART Score може бути використана для титрування пацієнтів із загруднинним болем (можливим ГКС), які знаходяться у кареті швидкої допомоги, приймальному покої чи відділені невідкладної допомоги для прогнозування ризиків та визначення подальшої тактики (обстеження та лікування) таких хворих [3, 21, 33].

Шкала HEART була підтверджена в декількох дослідженнях i виявилася потужним, легким i, перш за все, практичним інструментом для розділення пацієнтів у групи з низьким, середнім та високим рівнем ризику. Дана шкала базується на обчисленні ризику «великої побічної серцевої події» (Major Adverse Cardiac Event (MACE)) протягом 6 тижнів, таких як загальна смертність, IM або коронарна реваскуляризація (табл. 4).

Пацієнти, які набрали 0-3 бали, мають 0,9$1,7 \%$ ризику несприятливих серцевих подій; оцінка 4-6 балів: 12-16,6 \% ризику несприятливих серцевих подій, оцінка $\geq 7$ : 50-65\% ризику несприятливих серцевих подій (кандидатами на ранні інвазивні заходи). Відповідно до шкали HEART відразу зрозуміло, який пацієнт має право на виписку без додаткових аналізів або екстрених інвазивних процедур.

Шкала HEART не використовується, якщо на ЕКГ реєструється нова елевація сегмента $\mathrm{ST} \geq 1$ мм або інші нові ЕКГ зміни, які вимагають негайного втручання; гіпотензія; тривалість життя менше 1 року або позасерцева /хірургічна/психіатрична хвороба або у клінічно нестабільних пацієнтів [21, 33]. 
HEART Score для паціснтів із загруднинним болем

Таблиця 4

\begin{tabular}{|c|c|c|c|}
\hline & & Показник & Бал \\
\hline \multirow{3}{*}{$\mathbf{H}$} & \multirow{3}{*}{ History/Анемнез * } & викликають слабку підозру & 0 \\
\hline & & середня ступінь настороженості & 1 \\
\hline & & висока ступінь настороженості & 2 \\
\hline \multirow{3}{*}{$\mathbf{E}$} & \multirow{3}{*}{ Ecg / Електрокардіограма } & норма & 0 \\
\hline & & $\begin{array}{c}\text { немає відхилення сегмента ST, блокада ЛНПГ, } \\
\text { гіпертрофія ЛШ, порушення реполяризації } \\
\text { (дігоксин); }\end{array}$ & 1 \\
\hline & & виражене відхилення сегмента ST & 2 \\
\hline \multirow{3}{*}{$\mathbf{A}$} & \multirow{3}{*}{ Age/Вік } & $<45$ & 0 \\
\hline & & $45-64$ & 1 \\
\hline & & $\geq 65$ & 2 \\
\hline \multirow{3}{*}{$\mathbf{R}$} & \multirow{3}{*}{$\begin{array}{c}\text { Risk factors/Фактори } \\
\text { ризику** }\end{array}$} & відсутні & 0 \\
\hline & & 1 - 2 фактори ризику & 1 \\
\hline & & $\geq 3$ факторів ризику або атеросклероз в анамнезі & 2 \\
\hline \multirow{3}{*}{$\mathbf{T}$} & \multirow{3}{*}{$\begin{array}{l}\text { Initial troponin/ Рівень } \\
\text { тропоніну }\end{array}$} & $\leq$ норми & 0 \\
\hline & & 1-3 х норми & 1 \\
\hline & & $>3$ х норми & 2 \\
\hline
\end{tabular}

Примітки. *біль у грудях, що здавлює, іррадіація в щелепу/ліве плече/руку, тривалість 5-15 хв, причина: фізичне навантаження, холод, стрес, нудота/блювання, позитивна реакція на нітрати упродовж декількох хвилин, підтвердження симптомів пацієнтом. низький ризик: добре локалізований біль, не пов'язаний 3 фізичним навантаженням, відсутність підвищеного потовиділення, немає блювоти / нудоти, посилюється при пальпації.

** фактори ризику: АГ, гіперхолестеринемія, ЦД, ожиріння (імт $>30$ кг/м2), куріння (зараз або $\leq 3$ міс. тому), сімейний анамнез (батько або рідний брат/сестра молодше 65 років з ссз), що передують: ІМ, ЧКВ/АКШ, TIA/ГРМК, захворювання периферичних артерій).

Шкала PURSUIT (The pMeMglycoprotein IIb/IIIa in unstable angina: receptors uppres sionusingintegril in therapy) оцінює 30-денний, а також 12місячний ризик розвитку інфаркту міокарда (IM), нестабільної стенокардії (НС) та смерті і використовує градацію від 0 до 18 балів. Об'єктом аналізу стають такі показники як вік, стать, ЧСС, систолічний тиск (САТ), симптоми серцевої недостатності (СН), депресія сегмента ST (табл. 5).

Протокол цього дослідження був розроблений 3 метою вивчення ефективності ептіфібатіда (Інтегриліну), що призначався як доповнення стандартної терапії у хворих з ГКС. У дослідженні брали участь пацієнти, які були рандомізовані упродовж 24 годин від моменту появи симптомів НС або IM без зубця Q. Критеріями включення також були ішемічні зміни на ЕКГ без стійкої елевації сегмента ST, враховувалися рівень МВ-фракції креатинінкінази сироватки крові. Кількість кінцевих точок також проаналізовано через 96 годин від початку лікування [17].

Низький ризик - менше або дорівнює 12 балів (смертність $<10 \%$ за 30 діб).

Середній ризик - 13-14 балів (смертність 10$19 \%$ за 30 діб).

Високий ризик - більше 14 балів (смертність більше $19 \%$ за 30 діб).
Таблиця 5

\begin{tabular}{|c|c|c|}
\hline \multicolumn{3}{|c|}{ шкала PURSUI } \\
\hline \multicolumn{2}{|c|}{ Показник } & Бал \\
\hline \multirow[t]{4}{*}{ Вік } & $50-59$ & 8 \\
\hline & $60-69$ & 9 \\
\hline & $70-79$ & 11 \\
\hline & $>80$ років & 12 \\
\hline \multirow[t]{2}{*}{ Стать } & Чоловіки & 1 \\
\hline & Жінки & 0 \\
\hline \multicolumn{2}{|c|}{$\begin{array}{l}\text { Стенокардія III-IV ФК за попередні } 6 \\
\text { тижнів }\end{array}$} & 2 \\
\hline \multicolumn{2}{|c|}{$\begin{array}{l}\text { Симптоми серцевої } \quad \text { недостатності } \\
\text { (хрипи більше } 1 / 3 \text { поверхні легень) }\end{array}$} & 2 \\
\hline \multicolumn{2}{|c|}{ Депресія сегмента S-T } & 1 \\
\hline
\end{tabular}

Шкала GRACE, є, мабуть, найбільш потужною за своєю прогностичною цінністю $[1,6,7,11]$.

У 1999 p. був організований Глобальний реєстр ГКС (GLOBAL REGISTRY OF ACUTE CORONARY EVENTS - GRACE), який $є$ міжнародною базою даних по спостереженню за наслідками у хворих, що були госпіталізовані з ГКС (IM і НC). Метою було створення багатонаціонального реєстру з ГКС із включенням у дослідження 10000 хворих щорічно 3 різних демографічних груп [11]. Шкала ризику GRACE досить проста у використанні і дозволяє швидко й достовірно розрахувати і визначити ризик для кожного конкретного хворого (табл. 6, табл. 7 ) $[1,11,17,24]$.

Для розрахунку ризику за даною шкалою використовують такі дані: вік хворого, САТ і ЧСС під час госпіталізації, рівень креатиніну в сироватці, 
симптоми гострої серцевої недостатності по Кillip/Kimbal (I-IV), наявність або відсутність епізодів зупинки серця, відхилення сегмента ST від ізолініі, рівень біохімічних маркерів некрозу в крові (тропонін Т і ферменти).

\section{Оцінка ризику смерті у хворих з гострим коронарним синдромом без} елевації ST в стаціонарі та через 6 місяців за шкалою GRACE

Таблиця 6

\begin{tabular}{|c|c|}
\hline Фактор ризику & $\begin{array}{c}\text { Кількість } \\
\text { балів }\end{array}$ \\
\hline \multicolumn{2}{|l|}{ Вік (роки) } \\
\hline$\leq 30$ & 0 \\
\hline $30-39$ & 8 \\
\hline $40-49$ & 25 \\
\hline $50-59$ & 41 \\
\hline $60-69$ & 58 \\
\hline $70-79$ & 75 \\
\hline $80-89$ & 91 \\
\hline$\geq 90$ & 100 \\
\hline \multicolumn{2}{|c|}{ ЧСС (ударів в хвилину) } \\
\hline$\leq 50$ & 0 \\
\hline $50-69$ & 3 \\
\hline $70-89$ & 9 \\
\hline $90-109$ & 15 \\
\hline $110-149$ & 24 \\
\hline 150-199 & 38 \\
\hline$\geq 200$ & 46 \\
\hline \multicolumn{2}{|l|}{ Інші фактори } \\
\hline $\begin{array}{l}\text { Зупинка серця в момент гос- } \\
\text { піталізації }\end{array}$ & 39 \\
\hline $\begin{array}{c}\text { Зміщення сегмента ST, iнверсії } \\
\text { зубця T }\end{array}$ & 28 \\
\hline $\begin{array}{c}\text { Підвищений рівень маркерів } \\
\text { некрозу міокарда в крові }\end{array}$ & 14 \\
\hline
\end{tabular}

\begin{tabular}{|c|c|}
\hline Фактор ризику & $\begin{array}{c}\text { Кількість } \\
\text { балів } \\
\end{array}$ \\
\hline \multicolumn{2}{|c|}{ Систолічний АТ (мм рт. ст.) } \\
\hline$\leq 80$ & 58 \\
\hline $80-99$ & 53 \\
\hline $100-119$ & 43 \\
\hline $120-139$ & 34 \\
\hline $140-159$ & 24 \\
\hline $160-199$ & 10 \\
\hline$\geq 200$ & 0 \\
\hline $\begin{array}{l}\text { Рівень креатиніну в крові } \\
\text { ммоль/л-1) }\end{array}$ & (мг/дл \\
\hline \begin{tabular}{|c|c|}
$0-0,39 / 0-35,3$ & \\
\end{tabular} & 1 \\
\hline $0,40-0,79 / 35,4-70$ & 4 \\
\hline $0,80-1,19 / 71-105$ & 7 \\
\hline $1,20-1,59 / 106-140$ & 10 \\
\hline $1,60-1,99 / 141-176$ & 13 \\
\hline $2,0-3,99 / 177-353$ & 21 \\
\hline \begin{tabular}{l|l}
$\geq 4,0 / \geq 353$ \\
\end{tabular} & 28 \\
\hline \multicolumn{2}{|l|}{ Клас ГСН за Killip } \\
\hline T & 0 \\
\hline II & 20 \\
\hline III & 39 \\
\hline IV & 59 \\
\hline
\end{tabular}

Таблиця 7

Оцінка ризику смерті в стаціонарі й до 6-ти місяців після виписки при ГКС з елевацією сегмента ST за шкалою GRACE

\begin{tabular}{|l|l|l|}
\hline Категорія ризику & Бал за шкалою GRACE & А. Смертність в стаціонарі, \% \\
\hline Низька & $\leq 125$ & $<2$ \\
\hline Проміжна & $126-154$ & $2-5$ \\
\hline Висока & $155-319$ & $>5$ \\
\hline Категорія ризику & Бал за шкалою GRACE & $\begin{array}{l}\text { Б. Смертність до 6-го міс. після } \\
\text { виписки із стаціонару, \% }\end{array}$ \\
\hline Низька & $\leq 99$ & $<4.4$ \\
\hline Проміжна & $100-127$ & $4.5-11$ \\
\hline Висока & $128-263$ & $>11$ \\
\hline
\end{tabular}

За сумарним балом хворі розподіляються у відповідну групу ризику: низького (<108), середнього (109-140) і високого (> 140).

Існує вдосконалена шкала GRACE (GRACE 2,0), що дозволяє оцінити у тому числі більш віддалений прогноз захворювання, а також шкала "miniGRACE" для оцінки прогнозу у випадках, коли рівень креатиніну та/або клас за Killip ще не відомі. Відповідні калькулятори розміщені в Інтернеті на сайті http://www.outcomes- umassmed. org /grace /acs_risk/acs_risk_content.html.
Шкала ТIMI (Thrombolisis In Myocardial Infarction), запропонована Antman і співавт. в 2000 p, заснована на даних двох відомих великомасштабних досліджень TIMI-IIB i ESSENCE, присвячених порівнянні нефракціонованого гепарину і еноксапарину при ГКС без елевації сегменту ST, на підставі чого був розроблений комплексний підхід до визначення ризику смерті, IM, рецидиву стенокардії i/aбо необхідності невідкладної реваскуляризації у хворих з ГКС без елевації сегмента ST [1, 6, 12, 18, 22].

У дослідженні ESSENCE під наглядом перебували хворі, які були госпіталізовані упродовж 24 
годин 3 моменту виникнення гострої ішемії міокарда без елевації сегмента ST на ЕКГ, що виникла в спокої. У якості кінцевої точки розглядалася сума випадків смерті, ГІМ і рецидивуючої стенокардії.

Дослідження TIMI IIB (Thrombolysis in Myocardial Infarction IIB Trial) - найбільш велике з проведених порівняльних клінічних досліджень низькомолекулярних гепаринів [16]. У дослідженні брали участь хворі з НC або IM, рандомізація виконувалася в перші 24 години від виникнення захворювання. При цьому більшість хворих (81 \%) мали також ішемічні зміни на ЕКГ i/або підвищені рівні маркерів некрозу міокарда в крові. У якості кінцевої точки розглядалася сума випадків смерті, IM (у тому числі повторних) і невідкладної реваскуляризації міокарда, виконаної в зв'язку з поновленням стенокардії (табл. 8).

Шкала TIMI для оцінки ризику у хворих 3 елевацією сегменту ST має дещо інший вигляд (табл. 9) $[18,28,29]$.

Шкала ТIMI для ГКС без елевації сегменту ST

\begin{tabular}{|l|c|}
\hline \multicolumn{1}{|c|}{ Фактор ризику } & Бал \\
\hline Вік старше 65 років & 1 \\
\hline Наявність 3-х і більше факторів атеросклерозу & 1 \\
\hline Раніше виявлений 50 \% і більше стеноз коронарної артерії & 1 \\
\hline Відхилення сегмента ST $\geq 0,5$ мм при госпіталізації & 1 \\
\hline Два і більше ангінозних нападу в попередні 24-х години & 1 \\
\hline Прийом аспірину останні 7 діб & 1 \\
\hline Підвищення кардіальних біомаркерів у сироватці крові & 1 \\
\hline
\end{tabular}

\begin{tabular}{|c|c|c|}
\hline Сума балів & Ризик, \% & Подія, термін настання \\
\hline $0-1$ & 4,7 & \\
\hline 2 & 8,3 & \multirow{2}{*}{ Вірогідність смерті, розвитку ІМ або } \\
\hline 3 & 13,2 & \multirow{2}{*}{ ішемії з невідкладною реваскуляризацією до 14 діб } \\
\hline 4 & 19,9 & \\
\hline 5 & 26,2 & \\
\hline $6-7$ & 40,9 & \\
\hline
\end{tabular}

Шкала TIMI II для ГКС з елевацією сегмента ST

\begin{tabular}{|c|c|c|}
\hline \multicolumn{2}{|c|}{ Фактори ризику } & Бали \\
\hline \multicolumn{2}{|c|}{ Вік старше 75 років } & 3 \\
\hline \multicolumn{2}{|l|}{ Вік $65-74$ роки } & 2 \\
\hline \multicolumn{2}{|c|}{ Цукровий діабет, гіпертонічна хвороба або стенокардія } & 1 \\
\hline \multicolumn{2}{|c|}{ АТ систолічний $\leq 100$ мм рт. ст. } & 3 \\
\hline \multicolumn{2}{|c|}{ ЧСС $\geq 100$ в хвилину } & 2 \\
\hline \multicolumn{2}{|c|}{ Серцева недостатність II - IV по T. Killip } & 2 \\
\hline \multicolumn{2}{|c|}{ Маса тіла $\leq 67$ кг } & 1 \\
\hline \multicolumn{2}{|c|}{ Передня локалізація IM або блокада лівої ніжки пучка Гіса } & 1 \\
\hline \multicolumn{2}{|c|}{ Початок реперфузійної терапії $\geq 4$ годин } & 1 \\
\hline Сума балів & Ризик, \% & $\begin{array}{c}\text { Подія, термін } \\
\text { настання }\end{array}$ \\
\hline 0 & 0,8 & \multirow{10}{*}{$\begin{array}{c}\text { Вірогідність летально- } \\
\text { го результату за } \\
30 \text { діб }\end{array}$} \\
\hline 1 & 1,6 & \\
\hline 2 & 2,2 & \\
\hline 3 & 4,4 & \\
\hline 4 & 7,3 & \\
\hline 5 & 12,0 & \\
\hline 6 & 16,0 & \\
\hline 7 & 23,0 & \\
\hline 8 & 27,0 & \\
\hline $9-14$ & 36,0 & \\
\hline
\end{tabular}

Таблиця 9

Шкала CADILLAC заснована на дослідженні Controlled Abciximaband Device Investigationto Lower Late Angioplasty Complications (табл. 10). Дана шкала розроблена для короткострокового і довгострокового прогнозування смертельного результату у хворих з IM із елевацією сегмента ST, які зазнали ЧКВ. Крім клінічних, дана шкала враховує лабора- торні показники (рівень гемоглобіну крові, швидкість клубочкової фільтрації) і ангіографічні особливості коронарного русла (кровотік у коронарному руслі після процедури і трьохсудинні ураження коронарних артерій) $[15,29]$. 
Таблиця 10

\begin{tabular}{|c|c|}
\hline \multicolumn{2}{|l|}{ Шкала CADILLAC } \\
\hline Фактор ризику & $\begin{array}{c}\text { Кількість } \\
\text { балів }\end{array}$ \\
\hline Фракція викиду менше 40 \% & 4 \\
\hline ШКФ менше 60 мл/хв & 3 \\
\hline ГCH Killip II-III & 3 \\
\hline Післяпроцедурний кровотік за ТІМІ 0-2 & 2 \\
\hline Вік старше 65 років & 2 \\
\hline Анемія & 2 \\
\hline $\begin{array}{|lc|}\text { Трьохсудинне } \\
\text { артерій }\end{array}$ & 2 \\
\hline
\end{tabular}

Низький ризик - 0-2 бали.

Проміжний ризик - 2-5 балів.

Високий ризик - 6 і більше балів.

Незважаючи на очевидні успіхи, досягнуті в сучасній інтервенційній кардіології й ангіології, проблема безпеки проведення втручань залишається актуальною. Контрастні речовини, що застосовуються для візуалізації судин, мають нефротоксичну дію, викликаючи контраст-індуковану нефропатію (КIH). Першим кроком для зменшення ризику розвитку КІН має бути ідентифікація пацієнтів з високим ризиком розвитку КІН за допомогою різних скрінінгових опитувальників, анкет та шкал. На даний час найбільш поширеною шкалою для оцінки ризику виникнення KIH є шкала R. Mehran у модифікації B. Barrett и P. Parfrey перед проведенням ендоваскулярних процедур (табл. 11) [4, 23]. До факторів ризику автори віднесли клінічні стани, пов'язані 3 пацієнтом та 3 процедурою. На підставі сумарної оцінки балів визначається категорія ступеня ризику: низька, помірна, висока та дуже висока. Відповідно, імовірність гострого зниження функції нирок зростає iз збільшенням сумарного балу ризику.

Таблиця 11

\begin{tabular}{|c|c|c|c|}
\hline \multicolumn{3}{|c|}{ Фактор ризику } & Бал \\
\hline \multirow[t]{3}{*}{$\begin{array}{l}\text { Знижена ренальна } \\
\text { перфузія }\end{array}$} & \multicolumn{2}{|c|}{$\begin{array}{l}\text { Гіпотензія (САД <80 мм рт. ст.) упроовж } 1 \text { год. вима- } \\
\text { гає введення інотропів або інтрааортального балону } \\
\text { впроовж } 24 \text { год }\end{array}$} & 5 \\
\hline & \multicolumn{2}{|c|}{ Внутріаортальна контрпульсація } & 5 \\
\hline & \multicolumn{2}{|c|}{$\begin{array}{l}\text { Хронічна серцева недостатність ФК III-IV NYHA } \\
\text { i/або набряк легень }\end{array}$} & 5 \\
\hline Вік & \multicolumn{2}{|c|}{ Більше 75 років } & 4 \\
\hline Анемія & \multicolumn{2}{|c|}{ Гематокрит <39 \% для чоловіків і <36 \% для жінок } & 3 \\
\hline \multicolumn{3}{|l|}{ Цукровий діабет } & 3 \\
\hline \multicolumn{3}{|l|}{ Об’єм контрасту } & 1 бал на кожні 100 мл \\
\hline $\begin{array}{l}\text { Вихідне порушен- } \\
\text { ня функції нирок }\end{array}$ & \multicolumn{2}{|c|}{$\begin{array}{l}\text { Креатинін сироватки }>1,5 \text { мг / дл } \\
\text { або ШКФ (за MDRD): < } 60 \text { мл / хв/ 1,73м² }\end{array}$} & $\begin{array}{c}4 \\
2 \text { бали для 40-60 } \\
\text { мл/хв/1,73м² } \\
4 \text { бали для } 20-40 \\
\text { мл/хв/1,73м² } \\
6 \text { балів для <20 } \\
\text { мл/хв/1,73м² } \\
\end{array}$ \\
\hline \multicolumn{4}{|c|}{ Оцінка ризику } \\
\hline & Бал & $\begin{array}{l}\text { Частота розвитку } \\
\text { КІН }\end{array}$ & Необхідність діалізу \\
\hline \multicolumn{2}{|c|}{ Низький ризик ( $\leq 5$ бала) } & $7,5 \%$ & $0,04 \%$ \\
\hline \multicolumn{2}{|c|}{ Середній ризик (6-10 балів) } & $14 \%$ & $0,12 \%$ \\
\hline \multicolumn{2}{|c|}{ Високий ризик (11-16 балів) } & $26,1 \%$ & $1,09 \%$ \\
\hline \multicolumn{2}{|c|}{ Дуже високий ризик ( $\geq 16$ балів) } & $57,3 \%$ & $12,6 \%$ \\
\hline
\end{tabular}

Шкала DAPT (Dual Anti Platelet Therapy) peкомендована для оцінки ризику ішемічних і геморагічних ускладнень у хворих, які отримують подвійну $[19,25,36]$ антиагрегантну терапію (ПАТТ) інгібітором Р2Y12 рецепторів + аспірин більше 1 року, i визначення доцільності їі продовження хворим після стентування. Продовження ПАТТ на термін більше 1 року може бути доцільним хворим з ГКС без підйому сегмента ST або IM $з$ елевацією сегмента ST, яким проведено коронарне стентування. Це можливо при задовільній переносимості ПАТТ, відсутності геморагічних ускладнень на момент прийняття рішення або підвищеного ризику кровотеч, пов'язаних з епізодами (в анамнезі) на фоні прийому ПАТТ, коагулопатій, при зміні пероральних антикоагулянтів (Клас IIb). Шкала оцінки ризику DAPT, заснована на однойменному дослідженні, може виявитися корисною в прийнятті рішень щодо продовження (збільшення тривалості) ПАТТ у хворих, яким проведено коронарне стентування (табл. 12 ).

Сума балів 2 і більше асоційована зі сприятливим співвідношенням користь/ризик, що побічно вказує на користь збільшення термінів проведення ДАТ, у той час як сума менше 2 балів побічно вказує 
на несприятливий характер цього співвідношення (користь продовження терапії може виявитися нижче очікуваного).

На даний час тривалість ПАТТ рекомендують проводити на основі клінічної характеристики хворого, використовуючи шкалу PRECISE-DAPT (PREdicting bleeding Complications In patient sundergoing Stent implantation and subsEquent Dual AntiPlatelet Therapy) або використовувати онлайн калькулятор www.precisedaptscore.com. (табл. 12).

Шкала CRUSADE розроблена на матеріалі pеєстру ГКС (CanRapid risk stratification of Unstable angina patients Suppress ADverse outcomes with Early implementation of theACC/AHA Guidelines), який проводиться в США; проводиться оцінка ризику кровотеч у період госпіталізації у хворих на ГКС без елевації сегменту ST [28, 31]. У число параметрів, пов'язаних з ризиком кровотеч за результатом багатофак- торного аналізу, увійшли вихідний гематокрит, кліренс креатиніну, ЧСС, жіноча стать, симптоми СН, захворювання судин в анамнезі, цукровий діабет, САТ (табл. 13). Ці фактори були використані для створення шкали, у якій конкретним значенням фактора пов'язане певне число балів, підсумовування яких дає оцінку, що дозволяє віднести стан хворого до однієї з категорій ризику.

Виділено наступні категорії ризику виникнення кровотечі під час госпіталізації:

дуже низький (менше 20 балів);

низький (21-30 балів);

помірний (31-40 балів);

високий (41-50 балів);

дуже високий (більше 50).

Шкали DAPT та PRECISE-DAPT для прийняття рішення щодо тривалості подвійної

Таблиця 12 антитромбоцитарної терапії

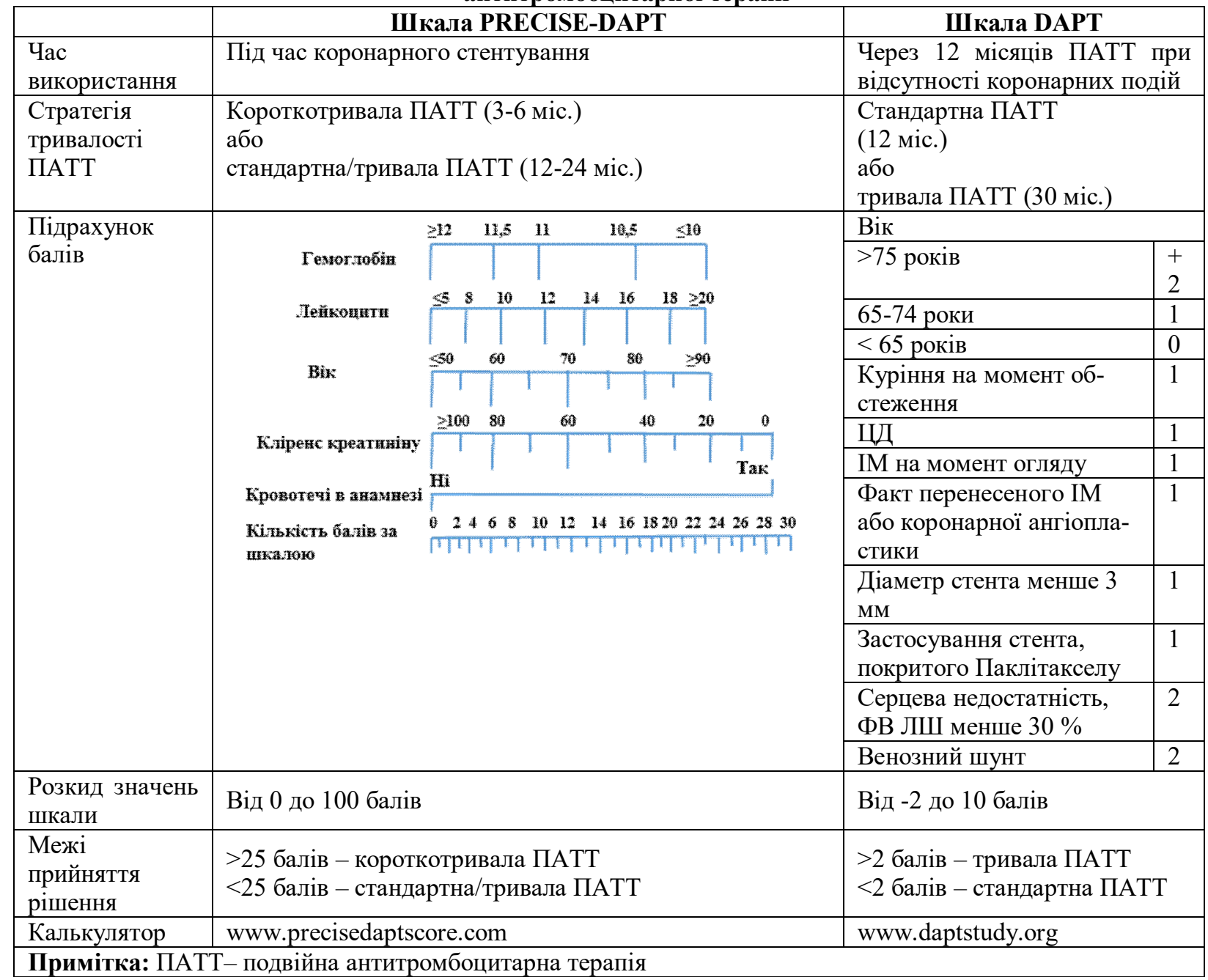


Таблиця 13

Оцінка ризику кровотечі за даними ресстру CRUSADE

\begin{tabular}{|l|c|}
\hline \multicolumn{1}{|c|}{ Предиктор } & Бали \\
\hline \multicolumn{2}{|c|}{ Базовий рівень гематокриту, \% } \\
\hline$<31$ & 9 \\
\hline $31-33,9$ & 3 \\
\hline $34-36,9$ & 2 \\
\hline $37-39,9$ & 0 \\
\hline$>40$ & 39 \\
\hline \multicolumn{2}{|c|}{ Кліренс креатиніну, мл/хв. } \\
\hline$<15$ & 35 \\
\hline$>15-30$ & 28 \\
\hline$>30-60$ & 17 \\
\hline$>60-90$ & 7 \\
\hline$>90-120$ & 0 \\
\hline$>121$ & 0 \\
\hline \multicolumn{2}{|c|}{ Стать } \\
\hline Чоловіча & 8 \\
\hline Жіноча & 0 \\
\hline \multicolumn{2}{|c|}{ Наявність ознак СН } \\
\hline Ні & 7 \\
\hline Так & 0 \\
\hline Ні & 6 \\
\hline Так & 0 Хопередні хвороби судин \\
\hline
\end{tabular}

\begin{tabular}{|l|c|}
\hline \multicolumn{1}{|c|}{ Предиктор } & Бали \\
\hline \multicolumn{2}{|c|}{ Частота скорочень серця } \\
\hline$<70$ & 0 \\
\hline $71-80$ & 1 \\
\hline $81-90$ & 6 \\
\hline $91-100$ & 8 \\
\hline $101-110$ & 10 \\
\hline $111-120$ & 11 \\
\hline$>121$ & 0 \\
\hline \multicolumn{2}{|c|}{ Цукровий діабет } \\
\hline Hi & 6 \\
\hline Tак & 10 \\
\hline Систолічний артеріальний тиск, мм. рт.ст. \\
\hline$<90$ & 8 \\
\hline $91-100$ & 5 \\
\hline $101-120$ & 1 \\
\hline $121-180$ & 3 \\
\hline $181-200$ & 5 \\
\hline$>201$ & \\
\hline
\end{tabular}

Шкала GUSTO (Global Utilization of Streptokinase and Tissueplasminogen activatortotre at Occluded arteries-1) застосовується для оцінки 30-денного прогнозу у хворих з ГКС при госпіталізації в стаціонар поряд 3 віком, визначеними даними серцево- судинного анамнезу (наявність перенесеного інсульту або IM, CH) додаткові клінічні фактори, такі як тахікардія, підвищення показників кардіальних біомаркерів, С-реактивного білка, креатіну, а також факту наявності анемії (табл. 14 ) [8, 30].

Таблиця 14

Шкала стратифікації ризику GUSTO

\begin{tabular}{|c|c|c|c|}
\hline \multicolumn{3}{|c|}{ Фактори ризику } & Бал \\
\hline \multirow{4}{*}{ Вік } & \multicolumn{2}{|c|}{$50-59$ років } & 2 \\
\hline & \multirow{2}{*}{\multicolumn{2}{|c|}{$\frac{60-69 \text { років }}{70-79 \text { років }}$}} & 4 \\
\hline & & & 6 \\
\hline & \multicolumn{2}{|c|}{$>80$} & 8 \\
\hline \multicolumn{3}{|l|}{ Серцева недостатність } & 2 \\
\hline \multicolumn{3}{|c|}{ Інсульти, минуща ішемія мозку } & 2 \\
\hline \multicolumn{3}{|c|}{ IM, реваскуляризація або стабільна стенокардія } & 1 \\
\hline \multicolumn{3}{|c|}{ ЧСС $>90$ в хвилину } & 3 \\
\hline \multicolumn{3}{|c|}{ Підвищення тропоніну або МВ КФК } & 3 \\
\hline \multicolumn{3}{|c|}{ Креатинін> 1,4 мг \% } & 2 \\
\hline \multicolumn{3}{|l|}{ СРБ> 20 мг / л } & 2 \\
\hline \multicolumn{3}{|l|}{ СРБ $10-20$ мг / л } & 1 \\
\hline \multicolumn{3}{|l|}{ Анемія } & 1 \\
\hline Сума балів & \multicolumn{2}{|l|}{ Ризик \% } & Подія, термін настання \\
\hline $0-5$ & \multirow{2}{*}{$\begin{array}{l}0,4 \\
28\end{array}$} & \multirow{5}{*}{\multicolumn{2}{|c|}{$\begin{array}{c}\text { Імовірність летального результату за } \\
30 \text { діб }\end{array}$}} \\
\hline $6-10$ & & & \\
\hline $11-15$ & 8,7 & & \\
\hline $16-19$ & 25,0 & & \\
\hline $20-22$ & 41,7 & & \\
\hline
\end{tabular}

Висновки. Таким чином, використання прогностичних шкал на практиці допомагає лікарям оцінити можливі ризики розвитку несприятливих подій для груп пацієнтів 3 подібними умовами, і на цій основі приймати більш ефективні діагностичні і лікувальні рішення з обов'язковим урахуванням позиції 
пацієнта, особливостей хвороби, коморбідності, генетичних факторів і факторів середовища.

\section{References:}

1. Alexander KP, Bach RG, Chen AY, et al. Bleeding and Ischemic Events Run Parallel in NSTEMI Patients. J Amer Coll Cardiol. 2008; 51:1017-76.

2. Apostolakis S, Sullivan RM, Olshansky B, et al. Factors affecting quality of anticoagulation control among patients with atrial fibrillation on warfarin: the SAMe-TT2R2 score. Chest 2013; 144:155-63.

3. Backus BE, Six AJ, Doevendans PA, et al. Prognostic factors in chest pain patients: a quantitative analysis of the HEART score. Crit Pathw Cardiol. 2016; 15:50-55.

4. Barrett BJ, Parfrey PS. Clinical practice. Preventing nephropathy induced by contrast medium. N Engl J. Med, 2006; 354(4):379-86. DOI: 10.1056/ NEJMcp050801.

5. Belialov F. Prognosis and scores in cardiology. M: MEDpress-inform, 2018. P.300. (in Russ).

6. Carmo P, Ferreira J, Aguiar C, et al. Doescontinuous ST-segment monitoring add prognosti cinformation to the TIMI, PURSUIT, and GRACE risks cores? Ann. Noninvasive Electrocardiol. 2011; 16(3):239-249.

7. Carruthers KF, Dabbous OH, Flather MD, Starkey I, et al. Contemporary management of acute coronary syndromes: Does the practice match the evidence? The Global Registry of Acute Coronary Events (GRACE). Heart. 2005; 91(3):290-298. DOI: 10.1136/hrt.2003.031237.

8. Empana JP, Ducimetiere P, Arveiler D. et al. Are the Framingham and PROCAM coronary heart disease risk function applicable to different European populations? Eur. Heart. J. 2009; 24:1903-1911.

9. ESC/EAS 2019 Guidelines for themanagement of dyslipidaemias: lipid modification to reduce cardiovascular risk. The Task Force for the management of dyslipidaemias of the European Society of Cardiology (ESC) and European Atherosclerosis Society (EAS) European Heart Journal European Heart Journal. 2020; 41:111-188. DOI:10.1093/eurheartj/ehz455

10. Fanola CL, Giugliano RP, Ruff CT, et al. A novel risk prediction score in atrial fibrillation for a net clinical outcome from the ENGAGE AF-TIMI 48 randomized clinical trial. European Heart Journal. 2017; 00:1-9. DOI:10.1093/eurheartj/ehw565

http://eurheartj.oxfordjournals.org/content/early/2017/ 01/06/eurheartj.ehw565

11. Fox KAA, Dabbous OH, Goldberg RJ. Prediction of risk of death and myocardial infarction in the six months after presentation with acute coronary syndrome:prospective multinational observational study (GRACE). Br. Med. J., 2006; 333:1091-1094.

12. Garcia S, Canoniero M, Peter A et al. Correlation of TIMI risk score with angiographic severity and extent of coronary artery disease in patients with non-STelevation acute coronary syndromes. Am J Cardiol. 2004; 93:813-816.

13. Genders TS, Steyerberg EW, Nieman K, Galema TW, et al. Prediction model to estimate presence of coro- nary artery disease: retrospective pooled analysis of existing cohorts. BMJ. 2012; 344:3485.

14. Goldenberg I, Vyas AK, Hall WJ, et al. Risk stratification for primary implantation of a cardioverter-defibrillator in patients with ischemic left ventricular dysfunction. J Am Coll Cardiol. 2008; 51(3):88-96.

15. Guagliumi G, Stone GW, Cox DA. et al. Outcome in Elderly Patients Undergoing Primary Coronary Intervention for Acute Myocardial Infarction Results From the Controlled Abciximab and Device Investigation to Lower Late Angioplasty Complications (CADILLAC) Trial. Circulation. 2004; 21: 1598-04.

16. Januzzi JL Jr1, Newby LK, Murphy SA, et al. Predicting a late positive serum troponin in initially troponin-negative patients with non-ST-elevation acute coronary syndrome: clinical predictors and validated risk score results from the TIMI IIIB and GUSTO IIA studies Am Heart J. 2006; 151(2):360-6.

17. Khalill R, Lei H, Chang J. The TIMI, GRACE or PURSUIT risk models. The use of risksc or es for stratification of acute coronary syndrome patients. Br. J. Cardiol. 2009; 16(6):265-267.

18. Lakhani MS, Qadir F, Hanif B et al. Correlation of thrombolysis in myocardial infarction (TIMI) risk score with extent of coronary artery disease in patients with acute coronary syndrome. J Pak Med Assoc, 2010; 60:197-200.

19. Levine GN. et. al. 2016 ACC/AHA Guideline Focused Updateon Duration of Dual Antiplatelet Therapy in Patients With Coronary Artery Disease. 2016; 134:156-178.

20. Lia X, Sousa-Casasnovas I, Devesa C. Et.al. Predictors of in-hospital mortality among cardiogenic shock patients. Prognostic and the rapeutic implications. Int J Cardiol. 2016, Dec.1; 224:114-118.

21. Mahler SA, Riley RF, Hiestand BC, et al, The HEART Pathway randomized trial: identifying emergency department patients with acute chest pain for early discharge. Circ Cardiovasc Qual Outcomes. 2015; 8:195-203.

22. McNamara RL, Kennedy KF, Cohen DJ, et al. Predicting In-Hospital Mortality in Patients With Acute Myocardial Infarction. J Am Coll Cardiol 2016; 68:626.

23. Mehran R, Aymong ED, Nikolsky E, et al. A simple risk score for prediction of contrast-induced nephropathy after percutaneous coronary intervention: development and initial validation. J. Am. Coll. Cardiol. 2004; 44:1393-1399.

24. Naqvi SHR, Abbas T, Tun HN, Naqvi AA, Zaffar Z, et al. Diagnostic accuracy of TIMI versus GRACE score for prediction of death in patients presenting with Acute Non-ST Elevation Myocardial Infarction (NSTEMI). J Cardiol Cardiovasc Med. 2019; 4:001005. https://doi.org/10.29328/journal.jccm.1001032

25. Ozkan B, Uysal OK, Duran M, et. al. Relationship between mean platelet volume and a the rosclerosisin young patients with ST elevation myocardial infarction. Angiology. 2013, Jul; 64(5):371-4. 
26. Peterson JC, Paget SA, Lachs MS, et al. (2011) The risk of comorbidity. ARD (http://dx.doi.org/ 10.1136/annrheumdis-2011-200473).

27. Piepoli MF, Hoes AW, Agewall S, et al. European Guidelines on cardiovascular disease prevention in clinical practice: The sixth joint task force of the European Society of Cardiology and other societies on cardiovascular disease prevention in clinical practice (constituted by representatives of 10 societies and by invited experts) developed with the special contribution of the European Association for Cardiovascular Prevention \& Rehabilitation (EACPR). Eur. Heart J. 2016; 37(29):2315-2381. DOI: 10.1093/eurheartj/ehw106.

28. Roe MT, Chen AY, Thomas L, et al. Predicting longterm mortality in older patients after non-ST-segment elevation myocardial infarction: the CRUSADE longterm mortality model and risk score. Am Heart J 2011; 162:875.

29. Scruth EA, Cheng E, Worrall-Carter L. Risk score comparison of outcomes in patients presenting with ST-elevation myocardial infarction treated with percutaneous coronary intervention. Eur J Cardiovasc Nurs. 2013. Aug.; 1 2(4):330-6.

30. Simoons ML, GUSTO IV-ACS Investigators. Effect of glycoprotein $2 \mathrm{~b} / 3 \mathrm{a}$ receptor blocker abciximab on outcome in patients with acute coronary syndromes without early coronary revascularization: The GUSTO 4-ACS randomised trial. Lancet, 2001; 357:1915-1924.

31. Subherwal S, Bach RG, Chen AY. et. al. The CRUSADE Bleeding Score to Assess Baseline Risk of Major Bleeding in Non-ST-Segment Elevation Myocardial Infarction. J Amer Coll Cardiol 2008; 51, Suppl A: abstr 806-9. http://www.cardiosource. com/rapidnewssummaries/summary.asp?EID=31\&Do $\mathrm{W}=$ Mon \&SumID $=317$.

32. Ting He, Xing Liu, Nana Xu, Diagnostic models of the pre-test probability of stable coronary artery disease: A systematic review. CLINICS 2017; 72(2):188-196. DOI: 10.6061/clinics/2017(03)10.

33. Van Den Berg P, Body R. The HEART score for early rule out of acute coronary syndromes in the emergency department: a systematic review and metaanalysis. Eur Heart J Acute Cardiovasc Care, 2018; 7:111-119.

34. Winkle RA, Jarman JW, Mead RH, et al. Predicting atrial fibrillation ablation outcome: The CAAP-AF score. Heart Rhythm. 2016. Jul.; 17: 15475271(16):30548-3.

35. Yashchenko OB, Khimion LV, Danyliuk SV, Sytiuk TO. Ctabilna ishemichna khvoroba sertsia. Semeinaia medytsyna. 2018; 4(78):5-15.

36. Yeh RW, Secemsky EA, Kereiakes DJ, et al. Development and Validation of a Prediction Rule for Benefit and Harm of Dual Antiplatelet Therapy Beyond 1 Year After Percutaneous Coronary Intervention. JAMA. 2016; 315(16):1735-49.

\section{УДК 616-037+612.17 \\ ПРИМЕНЕНИЕ ПРОГНОСТИЧНЫХ ШКАЛ В СОВРЕМЕННОЙ КАРДИОЛОГИЧЕСКОЙ ПРАКТИКЕ (ЧАСТЬ 1)}

\author{
И.П. Вакалюк ${ }^{1}$, Н.М. Середюк ${ }^{1}$, Р.В. Денина ${ }^{1}$, \\ Г.Г. Барила ${ }^{1}$, И.К. Чурпий ${ }^{2}$, А.В. Янив ${ }^{2}$
}

\author{
Ивано-Франковский нацุиональный медицинский \\ университет, \\ ${ }^{1}$ кафедра внутренней медицинь №2 u \\ медсестринства, \\ ${ }^{2}$ кафедра физической реабилитащчии, эрготерапии с \\ курсом физического воспитания, \\ 2. Ивано-Франковск, Украина, \\ ORCID ID: 0000-0002-4430-6816, \\ ORCID ID: 0000-0002-3616-2445, \\ ORCID ID: 0000-0001-8196-7130, \\ ORCID ID: 0000-0002-0940-1092, \\ ORCID ID: 0000-0003-1735-9418, \\ ORCID ID: 0000-0003-0921-3304, \\ e-mail:roksolanadoc@ukr.net
}

Резюме. В данной статье представлены современные и наиболее популярные, хорошо зарекомендовавшие себя шкалы и калькуляторы, которые используются в практической медицине. Большой объем информации может создавать препятствия в обобщенные данных для получения достоверной оценки состояния пациента и принятия решения по диагностике, дальнейшей тактике лечения, оценки его эффективности и дальнейшего прогноза.

Положительным моментом в применении шкал есть и простота использования, что позволяет пользоваться ими в поликлиниках, семейных амбулаториях и стационарах.

Представленные шкалы позволяют проводить систематическую оценку коронарного риска, прогнозировать долгосрочные риски развития кардиоваскулярных событий, смертельных исходов и оценка длительности антитромбоцитарной терапии у пациентов при ОКС, определять риск тромбоэмболических осложнений у пациентов с фибрилляцией предсердий, оценить хирургический риск, связанный с реваскуляризацией миокарда и аорто-коронарным шунтированием.

Также факторы риска, которые используются в шкалах, часто бывают неспецифическими и могут влиять на прогноз других заболеваний. Например, возраст, курение, артериальное давление, патология почек, класс сердечной недостаточности, анемия, уровни липидов учитываются во многих шкалах. Поэтому шкалы, разработанные для одного заболевания, могут оказаться полезными и для других патологий.

Таким образом, использование прогностических шкал в практике помогает врачам оценить возможные риски развития неблагоприятных событий для групп пациентов с подобными условиями, и на этой основе принимать более эффективные диагно- 
стические и лечебные решения с обязательным учетом позиции каждого пациента.

Ключевые слова: прогностические шкалы, сердечно-сосудистый риск.

\section{UDC $616-037+612.17$}

\section{APPLICATION OF PROGNOSTIC SCALES IN MODERN CARDIOLOGICAL PRACTICE (PART 1)}

\author{
I.P. Vakaliuk ${ }^{1}$, N.M. Seredyuk ${ }^{1}$, R.V. Denina ${ }^{1}$, \\ H.H. Baryla ${ }^{1}$, I.K. Churpiy ${ }^{2}$, O.V. Yaniv ${ }^{2}$ \\ ${ }^{2}$ Department of Physical Rehabilitation, \\ Ivano-Frankivsk, Ukraine, \\ ORCID ID: 0000-0002-4430-6816, \\ ORCID ID: 0000-0002-3616-2445, \\ ORCID ID: 0000-0001-8196-7130, \\ ORCID ID: 0000-0002-0940-1092, \\ ORCID ID: 0000-0003-1735-9418, \\ ORCID ID: 0000-0003-0921-3304, \\ e-mail:roksolanadoc@ukr.net
}

Ivano- Frankivsk National Medical University, ${ }^{1}$ Department of Internal Medicine №2 and Nursing,

Ergotherapy with a course of Physical Education,

Abstract. This article presents the most popular and well-recommended scales and calculators used in practical medicine. A large amount of information can create obstacles in the aggregate data to obtain a reliable assessment of the patient's condition and make decisions about diagnosis, subsequent treatment tactics, evaluation of their effectiveness and further prognosis. A positive feature of the scales is the ease of use, which allows them to be used in clinics, family clinics and hospitals.

The presented scales allow to carry out a systematic evaluation of coronary risk, to predict long-term risks of cardiovascular events, fatal outcomes and assessment of the duration of antiplatelet therapy in patients with Acute Coronary Syndrome, to determine the risk of thromboembolic complications in patients with fibrillation with hysteresis and patients with fibrillation bypass. Also, the risk factors used in the scales are often nonspe- cific and may affect the prognosis of other diseases. For example, age, smoking, blood pressure, kidney pathology, heart failure class, anemia, lipid levels are considered on many scales. There fore, scales designed for one disease may be useful for other pathologies.

In this article (part 1) we provide an overview of the main scales that are recommended for use in cardiology practice. There are many internationally recognized and proven registries and scales for risk of Coronary Heart Disease and Acute Coronary Syndrome. According to the recommendations of the American Heart Association (ACC/AHA) and the European Society of Cardiology (ESC), the following registries and scales are most commonly used in practical cardiology: HEART Score, PURSUIT, TIMI, GRACE, CRUSADE (for patients with ACS without ST segment elevation), TIMI II (for patients with ACS and ST segment elevation); CADILLAC, SYNTAX, DAPT, PRECISE-DAPT, GUSTO, PAMI (when referring patients with percutaneous coronary intervention); CHA2DS2VASc, HAS-BLED, TIMI-AF, SAMe-TT2R2 (assessment of total risk of complications in patients with atrial fibrillation and to choose the optimal anticoagulation therapy); Charlson Index, Cumulative Illness Rating Scale, Index of Coexisting Disease (used to predict the risks of cardiovascular disease in conditions of comorbidity), and others.

Thus, the use of prognostic scales in practice helps clinicians to assess the potential risks of adverse events for groups of patients with similar conditions, and to make more effective diagnostic and treatment decisions based on each patient's position.

Scales for determining overall cardiovascular risk, including the SCORE (Systematic Coronary Risk Evaluation) scale, the Fremingham Scale for calculating a 10 -year risk of developing cardiovascular events in individuals with no clinical manifestations of cardiovascular pathology, are also the most common; The Reynolds Risk Scale estimates a 10-year cumulative risk of cardiovascular events (IM, ischemic stroke, coronary artery revascularization, and cardiovascular mortality).

Keywords: prognostic scales, cardiovascular risk. 